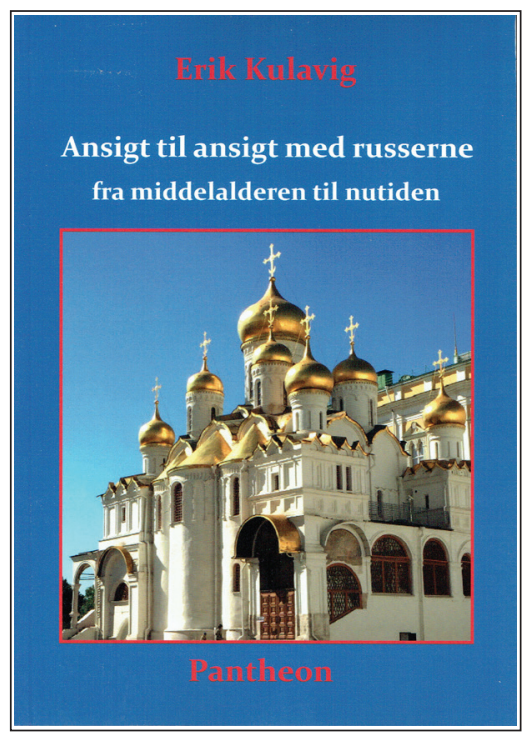

\title{
Ansigt til ansigt med russerne: Fra middelalderen til nutiden
}

\author{
Erik Kulavig \\ Valby: Pantheon \\ 239 sider. ISBN 9788790108861
}

Omtalt av Halvor Tjønn [journalist og forfatter, halvor.tjonn@gmail.com]

Gjennom nesten hele sin historie har Russland vært kjennetegnet av en autoritær statsmakt. Sivilsamfunnet har alltid vært svakt utviklet. Selv ikke adelen, den klassen som tsaren brukte som sitt instrument for å styre samfunnet, klarte gjennom 1700og 1800-tallet å spille noen viktig politisk rolle.

I 1905 ble riktignok viktige reformer tvunget gjennom, mot tsarens vilje. Så var det igjen en liberal periode mellom februar og oktober 1917, før bolsjevikpartiet overtok som statens enehersker. Under Boris Jeltsin på 1990-tallet kunne man på ny se konturene av et mer moderne Russland. Velgerne fikk i flere valg si sin mening om landets makthavere, og i økonomien kunne man se spirene til en virkelig markedsøkonomi.

Nyttårsaften 1999 kom Vladimir Putin til makten. Russland er tilbake på sin historiske hovedvei, med en sterk og kontrollerende statsmakt og med et sivilsamfunn med tilsvarende begrenset innflytelse. Til en viss grad har nok Putin forsøkt å opprettholde en balanse mellom tradisjon og fornyelse - mellom et autokratisk styre og en forsiktig form for modernisering. Det ser likevel ut til at han mer og mer faller ned på tradisjonens side. Dersom den utviklingen fortsetter, vil den samfunnsmessige virketrang og alt det borgerlige initiativet som Jeltsin-regimet åpnet opp for, bli kvalt. Skulle det skje, vil Russland uunngåelig havne i stagnasjon.

Med disse betraktningene avslutter lektor emeritus Erik Kulavig ved Institut for Historie og Center for Koldkrigsstudier, Syddansk Universitet, sin bok om Russlands historie. At Russland gjennom århundrene har pendlet mellom liberale, vestvendte perioder og autokratiske, isolasjonistiske epoker, er velkjent, men Kulavig stiller i sin bok denne utviklingen $i$ et skarpt relieff. Om noen av Putin-regimets støttespillere 
leser boka, må de spørre seg selv om hvorvidt den kursen Russland nå følger, leder landet inn i en ny Brezjnev-tid. Det var ikke bare en ideologisk og kulturell istid, det var en periode som ledet fram til det økonomiske sammenbruddet på slutten av 1980-tallet. På begynnelsen av 1990-tallet førte dette sammenbruddet ikke bare til at Sovjetunionen kollapset, men også til at Russlands eksistens som en enhetlig statsdannelse stod i fare.

Kulavig har gjennom sin karriere forsket på Russlands moderne historie. Fra og med 1970-tallet har han selv vært vitne til utviklingen. Ikke uventet er det beskrivelsen av det dramatiske 1900-tallet som er den desidert mest interessante delen av hans bok. Nikita Khrusjtsjov overtok fra Stalin en sentraldirigert, ikke-innovativ økonomi. Khrusjtsjov forstod at dersom det sovjetiske næringslivet skulle utvikles, måtte ansvaret for beslutningene delegeres nedover. Inntil da hadde man økt produksjonen ved hjelp av mer arbeidskraft og råvarer. Mot slutten av 1950-tallet klarte man faktisk også å øke produktiviteten per arbeider. Samtidig høstet Sovjetunionen store triumfer gjennom det spektakulære romprogrammet. I en kort periode kunne det for omverden se ut som om sovjetkommunismen var en suksess.

I stedet endte det hele med at Khrusjtsjov ble styrtet i 1964, og at en garde med systembevarere, med Leonid Brezjnev i spissen, tok over. Da Mikhail Gorbatsjov kom til makten i mars 1985, var egentlig løpet kjørt. Hans åpning for fri debatt glasnost - førte til at de underliggende spenningene kom til overflaten. I 1991 gikk Sovjetunionen i oppløsning.

Det er som sagt en glede å følge Kulavig gjennom Stalin-, Khrusjtsjov-, Brezjnev-, Gorbatsjov-, Jeltsin- og Putin-epoken. Det 20. og de første to tiår av det 21. århundre dekker da også to tredjedeler av boka. De øvrige 10 århundrer av russisk historie er beskrevet på kun 60-70 sider. Det sier seg selv at forfatteren må fare med harelabb over alle disse hundreårene. For eksempel er Smutnoje vremja, epoken som på dansk betegnes som "Den uklare tid", viktig for å forstå utviklingen av den russiske staten fra og med begynnelsen av 1600-tallet. Dessverre mangler denne analysen helt i Kulavigs bok.

Verre er det at mange av de enkeltopplysninger som gjengis spesielt i bokas første del, er gale. Om Ivan den grusomme heter det for eksempel at han hadde to sønner, Dmitrij og Fjodor. Det stemmer ikke; Ivan hadde tre sønner som vokste opp, nemlig Ivan Ivanovitsj, Dmitrij og Fjodor. Dmitrij ble ikke drept som toåring, som det står på side 22, men som åtteåring. Ivan Ivanovitsj blir altså ikke omtalt i teksten, men nevnes indirekte i en billedtekst under Ilja Repins monumentale bilde som framstiller Ivan den grusommes drap på sin sønn. I billedteksten blir det opplyst at det er høyst tvilsomt om Ivan slo sin sønn i hjel. Dét er det selvsagt ikke.

Flere feil følger: Det opplyses at den polske kongssønnen Vladislav «sætter sig på tronstolen i Kreml». Det er galt. Noen kretser innen den russiske adelen ønsket prins Vladislav som ny russisk tsar i 1610, men polakken klarte aldri fysisk å sette seg på tronstolen i Kreml. Så skriver Kulavig videre at «fyrst Razjevskij» i spissen for 
en russisk hær jager polakkene og den polske kongssønnen ut av Moskva. «Nogle vil vide, at man proppede ham $\mathrm{i}$ en stor kanon og skød ham ad Warszawa tily, står det å lese.

Intet av dette stemmer. Han som ledet den russiske oppstanden, het fyrst Pozjarskij, ikke Razjevskij. Vladislav kom aldri til Moskva og ble ikke skutt ut av noen kanon. Derimot ble Vladislav valgt til polsk konge i 1632 og regjerte fram til sin død i 1648. Det kunne vanskelig ha latt seg gjøre om han omkring 1610-1612 var blitt stappet ned i en kanon i Moskva.

Det vrimler av andre feil. På side 36 står det at Katarina II etterlot seg to sønner, Poul (Pavel) og Aleksander. På den påfølgende side er Aleksander, som korrekt er, blitt sønn av Pavel, og ikke hans bror. Går man fram til moderne tid, står det å lese på side 190 at folkeavstemmingen om Sovjetunionens framtid ble arrangert i mars 1990. Det korrekte er mars 1991. På side 200 står det at Jeltsin under et besøk i Tyskland i 2016 grep dirigentstokken foran et militærorkester. I 2016 hadde Jeltsin vært død i ni år, mens hans vert Helmut Kohl hadde vært pensjonist i 18 år. Det korrekte årstallet skulle selvsagt vært 1994. Årsaken til feilen kan være at det på nettet ligger et YouTube-opptak av episoden som er lastet opp i 2016. Det unnskylder ikke miseren.

Bøker skrevet av akademikere må forventes å inneholde en høy grad av nøyaktighet. Ansigt til ansigt med russerne tilfredsstiller ikke dette kravet, og det er synd. Det er å håpe at de mange feilene blir rettet opp i et seinere opplag av boka. 